\title{
Desulfurispirillum alkaliphilum gen. nov. sp. nov., a novel obligately anaerobic sulfur- and dissimilatory nitrate-reducing bacterium from a full-scale sulfide-removing bioreactor
}

\author{
D. Yu. Sorokin · M. Foti · B. J. Tindall • \\ G. Muyzer
}

Received: 17 September 2006/ Accepted: 2 November 2006/Published online: 23 January 2007

(C) Springer 2007

\begin{abstract}
Strain SR $1^{\mathrm{T}}$ was isolated under anaerobic conditions using elemental sulfur as electron acceptor and acetate as carbon and energy source from the Thiopaq bioreactor in Eerbeek (The Netherlands), which is removing $\mathrm{H}_{2} \mathrm{~S}$ from biogas by oxidation to elemental sulfur under oxygen-limiting and moderately haloalkaline conditions. The bacterium is obligately anaerobic, using elemental sulfur, nitrate and fumarate as electron acceptors. Elemental sulfur is reduced to sulfide through intermediate polysulfide, while nitrate is dissimilatory reduced to ammonium. Furthermore, in the presence of nitrate, strain SR $1^{\mathrm{T}}$ was able to oxidize limited amounts of sulfide to elemental sulfur during anaerobic growth with acetate. The new isolate is mesophilic and belongs to moderate haloalkaliphiles, with a $\mathrm{pH}$ range for growth (on acetate and nitrate)
\end{abstract}

Communicated by K. Horikoshi.

Nucleotide sequence accession number: the GenBank/EMBL accession number of the 16S rRNA gene sequence of strain SR $1^{\mathrm{T}}$ is DQ666683.

D. Yu. Sorokin $(\square)$

Winogradsky Institute of Microbiology,

Russian Academy of Sciences,

Prospect 60-let Octyabrya 7/2, 117811 Moscow, Russia

e-mail: soroc@inmi.host.ru; D.Y.Sorokin@tnw.tudelft.nl

D. Yu. Sorokin · M. Foti · G. Muyzer

Environmental Biotechnology Group,

Department of Biotechnology,

Delft University of Technology,

Julianalaan 67, 2628 BC Delft, The Netherlands

B. J. Tindall

DSMZ-Deutsche Sammlung von Mikroorganismen und Zellkulturen $\mathrm{GmbH}$, Inhoffenstrasse 7B,

Mascheroder Weg 1b, 38124 Braunschweig, Germany from 7.5 to 10.25 (optimum 9.0), and a salt range from 0.1 to $2.5 \mathrm{M} \mathrm{Na}^{+}$(optimum $0.4 \mathrm{M}$ ). According to phylogenetic analysis, SR $1^{\mathrm{T}}$ is a member of a deep bacterial lineage, distantly related to Chrysiogenes arsenatis (Macy et al. 1996). On the basis of the phenotypic and genetic data, the novel isolate is placed into a new genus and species, Desulfurispirillum alkaliphilum (type strain $\mathrm{SR}^{\mathrm{T}}=\mathrm{DSM} 18275=\mathrm{UNI}$ QEM U250).

Keywords Desulfurispirillum alkaliphilum .

Sulfur-reducing · Dissimilatory nitrate-reducing · Haloalkaliphilic

\section{Introduction}

The full-scale Thiopaq bioreactor in Eerbeek (The Netherlands) is aimed for the removal of $\mathrm{H}_{2} \mathrm{~S}$ from biogas, which is produced during anaerobic treatment of wastewater from paper-mill factories. The process is based on recently developed biotechnology of preferential sulfide oxidation to insoluble sulfur by lithoautotrophic sulfide-oxidizing bacteria under oxygen limitation (Buisman et al. 1990; Janssen et al. 1998). During a first physico-chemical step of the process, $\mathrm{H}_{2} \mathrm{~S}$ from the biogas is absorbed at a $\mathrm{pH}$ of around 8.7 by an alkaline solution, containing $\mathrm{NaHCO}_{3}$. The absorbed alkaline sulphide solution is fed into the bioreactor, operating at $35-45^{\circ} \mathrm{C}$ and -300 to $-350 \mathrm{mV}$ under oxygen-limiting conditions to facilitate incomplete oxidation of sulphide to elemental sulphur. This situation creates perfect conditions for a complete sulfur cycle, whereby both aerobic and anaerobic reactions involving sulfur compounds are possible. Lithoauto- 
trophic sulfide-oxidizing bacteria are the dominant populations in such reactors. They are producing elemental sulfur, as a major product, and thiosulfate and sulfate, as by-products, from sulfide, and organic compounds from $\mathrm{CO}_{2}$. The products then can be utilized by anaerobic sulfur-reducing, thiosulfate-reducing and sulfate-reducing bacteria, which are considered as unwanted components in such reactors (Buisman 1989). Furthermore, the development of a sulfurreducing population in the reactor is facilitated by the special properties of biologically-produced sulfur, which, in contrast to chemically-produced sulfur, is hydrophilic and has properties of colloidal particles (Janssen et al. 1996). Indeed, anaerobic enrichments at moderately haloalkaline, mesophilic conditions indicated the presence of an active population of the latter type, and resulted in the isolation of a haloalkaliphilic sulfur-reducing (respiring) bacterium strain SR 1, which is described below. Despite the intensive characterization of different functional groups of haloalkaliphilic bacteria (Jones et al. 1998; Zavarzin et al. 1999; Sorokin and Kuenen 2005), sulfur-respiring and dissimilatory nitrate-reducing representatives have yet not been found among the haloalkaliphilic communities in soda lakes. The bacterium described below represents a first example of such a type.

\section{Methods}

\section{Cultivation}

Enrichment and routine cultivation of haloalkaliphilic sulfur-reducing bacteria was performed at $30^{\circ} \mathrm{C}$ on a mineral medium containing sodium-bicarbonate, 0.6$0.8,0.1 \mathrm{M} \mathrm{NaCl}$, and $0.5 \mathrm{~g} \mathrm{l}^{-1}$ of $\mathrm{K}_{2} \mathrm{HPO}_{4}$. The $\mathrm{pH}$ was adjusted to 9.0 by addition of $\mathrm{Na}_{2} \mathrm{CO}_{3}$. After sterilization, the medium was supplemented with $20 \mathrm{mM}$ acetate as carbon and energy source, $50 \mathrm{mg} \mathrm{l}^{-1}$ of yeast extract, $4 \mathrm{mM} \mathrm{NH}_{4} \mathrm{Cl}, 1 \mathrm{mM} \mathrm{MgSO}_{4}$, and $1 \mathrm{ml} \mathrm{l}^{-1}$ of trace metal solution (Pfenning and Lippert 1966). Elemental sulfur was obtained from the Eerbeek Thiopaq reactor sludge as a thick suspension. It was separated from the cells by low-speed centrifugation, washed several times with distilled water, sterilized as $20 \%(\mathrm{v} / \mathrm{v})$ suspension in distilled water, washed again several times with sterile distilled water, and used at a final concentration of $30 \mathrm{mM}$. Other electron acceptors used were $\mathrm{KNO}_{3}(20 \mathrm{mM}), \mathrm{KNO}_{2}, \mathrm{Na}_{2} \mathrm{SO}_{3}$, sodium selenate and selenite, sodium arsenate, DMSO $(5 \mathrm{mM}$ each), sodium fumarate $(20 \mathrm{mM}$; alone or with $2 \mathrm{mM}$ acetate as carbon source), and freshly prepared ferrihydrite $(20 \mathrm{mM})$. Growth at microoxic conditions was tested with an oxygen concentration in the gas phase from 1 to $5 \%$. Anaerobic cultivation was performed in $60-100 \mathrm{ml}$ serum bottles with $40-80 \mathrm{ml}$ medium whereby air was replaced with argon. In some cases argon was replaced by $\mathrm{H}_{2}$ with 0.5 bar overpressure. Solid alkaline media with a final salt concentrations of $0.5 \mathrm{M} \mathrm{Na}^{+}$was prepared by $1: 1$ mixing of $4 \%(\mathrm{w} / \mathrm{v})$ agarose and $1 \mathrm{M} \mathrm{Na}^{+}$mineral medium at $50^{\circ} \mathrm{C}$. The plates were incubated in closed jars under argon atmosphere with an oxygen-scavenging catalyzer (Oxoid). The $\mathrm{pH}$ dependence was examined at $\mathrm{Na}^{+}$ content of $0.6 \mathrm{M}$, using the following filter-sterilized mineral medium: for $\mathrm{pH}$ 6-8, 0.1 M HEPES and $\mathrm{NaCl}$; for $\mathrm{pH} 8-11$, a mixture of sodium bicarbonate/sodium carbonate containing $0.1 \mathrm{M} \mathrm{NaCl}$. Growth resulted in a shift of initial $\mathrm{pH}$ values, especially in highly alkaline region; so only final $\mathrm{pH}$ values were used as suitable range for growth. To study the influence of salt concentration on growth, mineral media, containing 0.1 and $3.0 \mathrm{M}$ of total $\mathrm{Na}^{+}$were mixed in different proportions.

\section{Analytical procedures}

Chemical analysis of sulfur (sulfide, polysulfide, sulfur) and nitrogen (nitrate, nitrite, ammonium) compounds, and cell protein were performed as described previously (Sorokin et al. 2001, 2004). Phase contrast microphotographs were obtained with a Zeiss Axioplan Imaging 2 microscope (Göttingen, Germany). For electron microscopy, the cells were fixed with glutaraldehyde (final $3 \% \mathrm{v} / \mathrm{v}$ ) and positively contrasted with $1 \%(\mathrm{w} / \mathrm{v})$ uranyl acetate. Respiratory lipoquinones and polar lipids were extracted from $100 \mathrm{mg}$ of freeze-dried cells using the method described by Tindall (1990a, b). Respiratory lipoquinones were separated into their structural classes (menaquinones, ubiquinones, etc.) by TLC, bands eluted and further separated and identified by HPLC, using an $\mathrm{RP}_{18}$ column (Tindall 1996). Polar lipids were separated by two-dimensional chromatography and identified on the basis of their $R_{\mathrm{f}}$ values in combination with their reaction with specific staining reagents (Tindall 1990a, b). Fatty acid methyl esters were released from $20 \mathrm{mg}$ freeze-dried cells using methodologies, which release only ester linked fatty acids or ester and amide linked fatty acids (Labrenz et al. 2005; Strömpl et al. 1999).

Genetic and phylogenetic analysis

The isolation of the DNA and determination of the $\mathrm{G}+\mathrm{C}$ content of the DNA was performed according to Marmur (1961). Genomic DNA was extracted from 
the cells using the UltraClean Soil DNA Extraction Kit (MolBio Laboratories, USA), following the manufacture's instructions. The nearly complete $16 \mathrm{~S}$ rRNA gene was obtained using general bacterial primers GM3f (5'-AGAGTTTGATCCTGGCTCAG-3') and GM4r (5'-TACGGTTACCTTGTTACGACTT-3'). Sequencing was performed by the company BaseClear (Leiden, The Netherlands). The sequence was first compared to sequences stored in the GenBank database using BLAST search tool. Subsequently, the sequence was imported into the ARB software program (Ludwig et al. 2004), automatically aligned and manually checked. A tree was then generated using maximum likelihood.

\section{Results and discussion}

Enrichment and isolation of pure culture

Primary anaerobic enrichment cultures with acetate/ sulfur were positive for a $\mathrm{pH}$ range from 8 to 10 , and salt concentrations from 0.4 to $1.5 \mathrm{M}$ total $\mathrm{Na}^{+}$, closely matching the reactor conditions. During growth, two stages of sulfur transformation were observed: in the beginning, when sulfur was in excess, greenish-yellow polysulfide $\left(\mathrm{S}_{\mathrm{n}}^{2-}\right)$ was produced, which accumulated until all sulfur was dissolved. After that, the color started to disappear and all sulfur was finally converted to sulfide. MPN dilution series indicated the presence of up to $10^{6}$ viable cells in $1 \mathrm{ml}$ of reactor sample. From the highest positive dilution, a pure culture was isolated using sulfur-containing plates. Sulfur-reducing colonies formed clearing of the insoluble sulfur around them with yellow polysulfide as an intermediate stage (Fig. 1a). The strain was designated SR $1^{\mathrm{T}}$. The new isolate is a thin spirillum (Fig. 1b), highly motile with bipolar flagella (Fig. 1c).

\section{Growth characteristics and metabolism}

Strain SR $1^{\mathrm{T}}$ grew anaerobically at $\mathrm{pH} 9$ and salt concentration of $0.6 \mathrm{M} \mathrm{Na}^{+}$using biologically-produced sulfur as electron acceptor, which was first fully dissolved as polysulfide due to a chemical reaction with produced sulfide under alkaline conditions. At a later stage, polysulfide disappeared and sulfide was the final product (Fig. 2a). Chemical analysis demonstrated the presence of $S_{3}^{2-}$ (greenish) and $S_{4}^{2-}$ (yellow) as the dominant polysulfide species. The strain also could initiate growth with polysulfide $\left(\mathrm{S}_{6}^{2-}\right)$ instead of sulfur, but at a concentration of sulfan (terminal sulfide atoms) not higher than $10 \mathrm{mM}$. The $\mu_{\max }$ for growth under sulfur-reducing conditions was $0.12 \mathrm{~h}^{-1}$. From other tested electron acceptors, nitrate and fumarate were utilized. In case of nitrate, ammonia was identified as the final product, so the novel isolate belongs to dissimilatory nitrate reducers. Growth with acetate and nitrate as electron acceptor, instead of sulfur, was faster $\left(\mu_{\max }=0.19 \mathrm{~h}^{-1}\right)$, but the culture stopped growing
Fig. 1 Morphology of SR 1. a Colonies obtained from enrichment culture on sulfurcontaining alkaline agar; sulfur was first converted to polysulfide (greenishyellowish background) and finally to sulfide indicated by clearing zone around the active colonies. b Phasecontrast microphotograph of cells grown with acetate and nitrate. c Electron microphotograph of positively stained cell, bar $=1 \mu \mathrm{m}$. d Phase-contrast microphotograph of cells accumulating intracellular sulfur $(S)$ during oxidation of sulfide
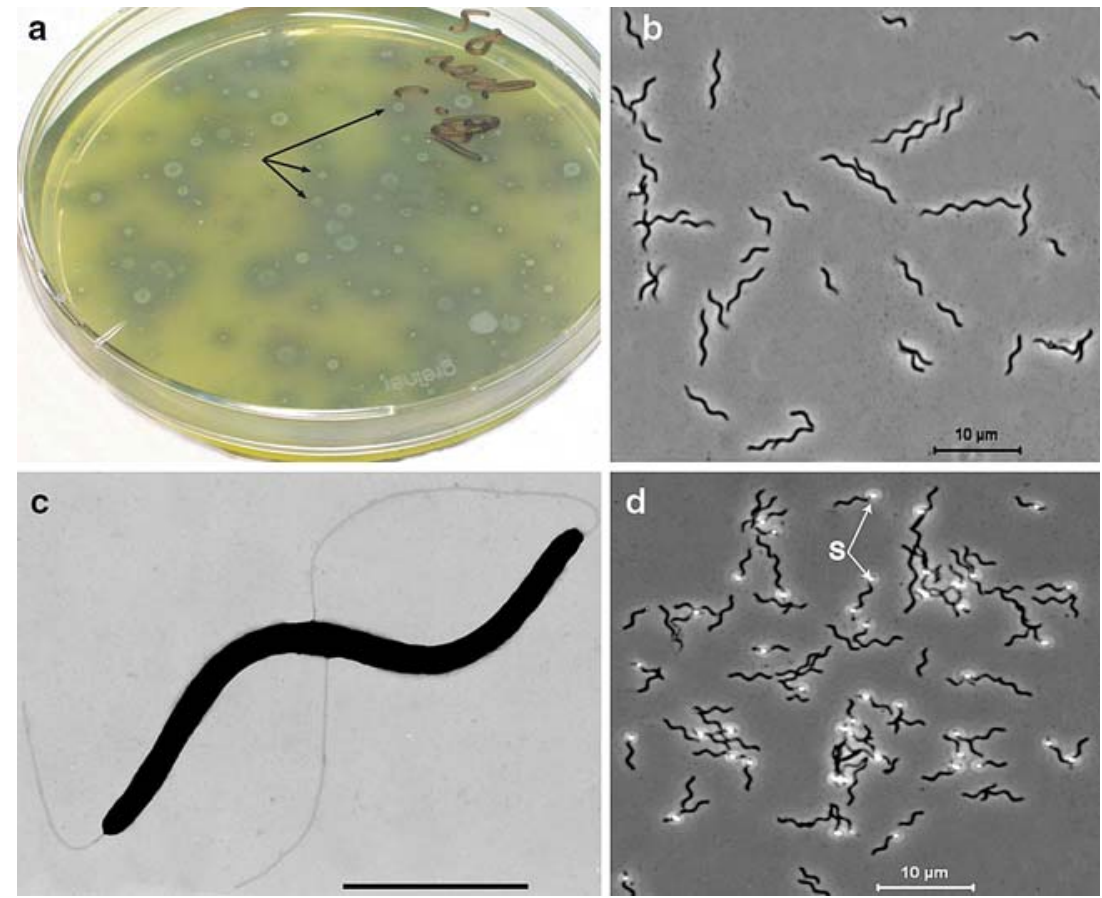

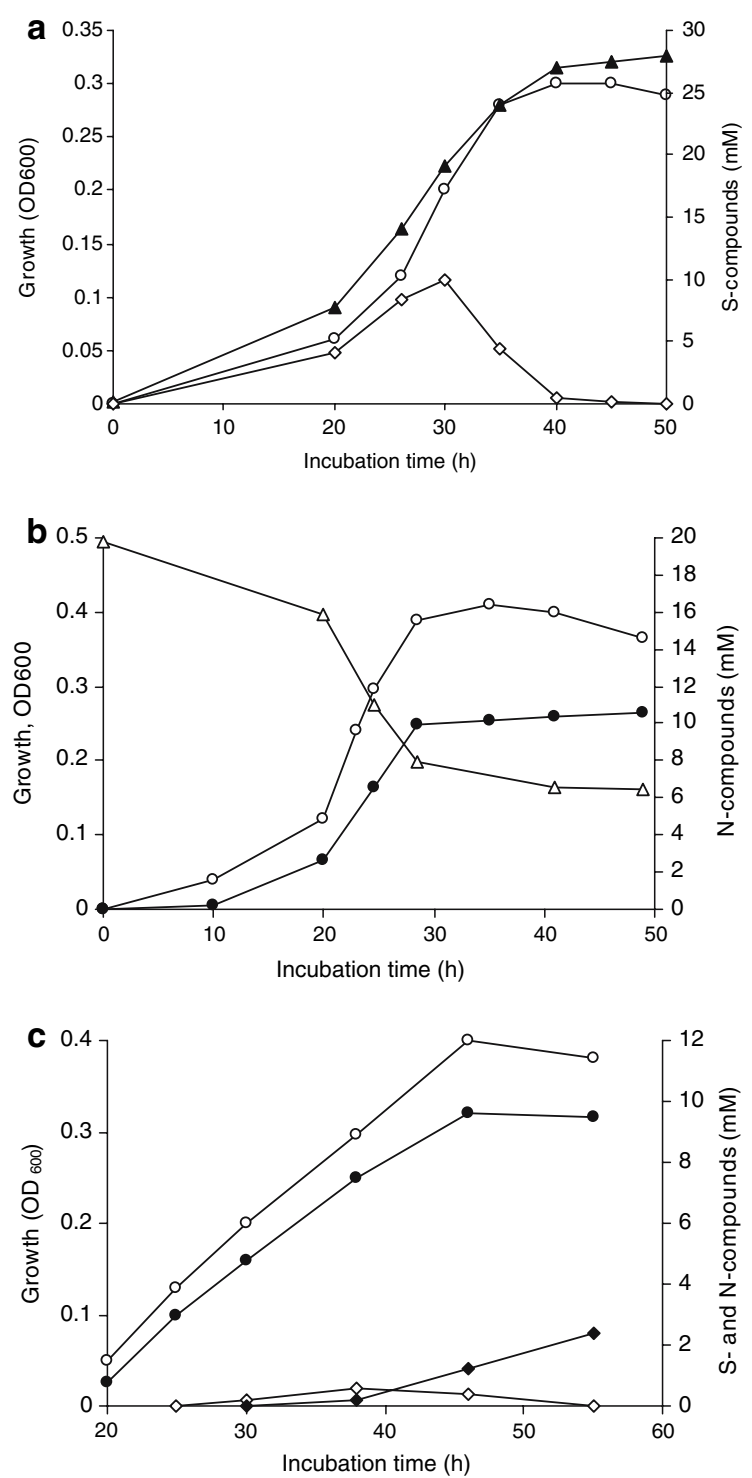

Fig. 2 Anaerobic growth and product accumulation of strain SR 1 at $\mathrm{pH} 9$ and $0.6 \mathrm{M} \mathrm{Na}^{+}$. a Growth with acetate + sulfur; b growth with acetate + nitrate; c oxidation of sulfide in culture growing with acetate + nitrate. Symbols: open circles biomass; closed circles $\mathrm{NH}_{3}$; open triangles nitrate; closed triangles total sulfane from $\mathrm{HS}^{-} / \mathrm{S}_{\mathrm{n}}^{2-}$; open diamonds elemental sulfur dissolved in polysulfide; closed diamonds insoluble elemental sulfur

before all the nitrate was reduced, probably due to toxicity of accumulating ammonia at high $\mathrm{pH}$ (Fig. 2b). Nitrite was not detected as an intermediate, however, it was the main product of nitrate reduction in experiments with washed cells. Most probably the nitrite-reductase was partially inactivated during cell harvesting under aerobic conditions. In case when both sulfur and nitrate were present as electron acceptors, sulfur reduction was initiated first and only after complete conversion of sulfur to sulfide nitrate reduction started slowly, in contrast to what might be expected from the rule of red-ox potentials. Most probably, the accumulation of polysulfide blocked nitrate reduction. A noticeable difference in color was observed for cells grown at sulfur-reducing and nitrate-reducing conditions: the sulfur-reducing biomass was black, while the nitrate-reducing biomass was bright red, due to a high concentration of a cytochrome $c 554$ (data not shown), probably associated with the presence of dissimilatory nitrite reductase $c c N I R$ (Simon 2002).

The bacterium could grow anaerobically in presence of fumarate as the only substrate $\left(\mu_{\max }=0.05 \mathrm{~h}^{-1}\right)$. Although we did not analyze the products, the only possible explanation for the growth at such conditions is fumarate fermentation. Addition of acetate as carbon source did not enhanced the final growth yield in fumarate-grown cultures. Addition of nitrate also did not affect the growth efficiency on fumarate, although up to $5 \mathrm{mM}$ nitrate was finally reduced to ammonia.

Strain SR $1^{\mathrm{T}}$ can utilize $\mathrm{H}_{2}$ as an alternative electron donor when acetate was supplied in limited amount ( $2 \mathrm{mM}$ instead of $20 \mathrm{mM}$ ) as the $\mathrm{C}$ source both with sulfur or nitrate as electron acceptors. In the presence of $\mathrm{H}_{2}$, the biomass yield increased 4-5 times with sulfur and 2-3 times with nitrate, respectively. With fumarate as the only substrate, addition of $\mathrm{H}_{2}$ did not stimulate the growth.

In experiments with washed cells, grown with acetate, nitrate and sulfide, it was $\mathrm{H}_{2}$, but not acetate, which was utilized as the preferable electron donor, and it was especially active in case of elemental sulfur as the electron acceptor. In case of nitrate, the product was nitrite.

Successful initiation of nitrate-reducing cultures was facilitated by adding sulfide as a reductant at $0.5-1 \mathrm{mM}$ concentrations. At the end of growth, sulfide was converted to elemental sulfur. So it seemed that SR $1^{\mathrm{T}}$ could reverse sulfur reduction reaction. This ability was proven by growing the isolate with $20 \mathrm{mM}$ acetate, $20 \mathrm{mM}$ nitrate and $3 \mathrm{mM}$ sulfide (Fig. 2c). Sulfide oxidation started in the late logarithmic phase with polysulfide as an intermediate and elemental sulfur as the final product. First, all elemental sulfur can be seen as tiny droplets inside the cells (Fig. 1d), which, on later stage, were excreted into the medium. With fumarate as the electron acceptor, the oxidation of sulfide, either in growing cultures or by washed cells, was not observed. The ability to oxidize sulfide to elemental sulfur was clearly manifested in the experiments with washed cells in presence of both nitrate and nitrite as electron acceptors. The estimated rate of sulfide oxidation in the presence of nitrate at $\mathrm{pH} 9$ was $26 \mathrm{nmol}(\mathrm{mg} \text { protein } \mathrm{min})^{-1}$. 
The results suggest an interesting combination of sulfur and nitrogen red-ox metabolism in SR $1^{\mathrm{T}}$ as summarized in Fig. 3. The dissimilatory nitrate- and sulfur-reducing Epsilonpoteobacteria Wolinella succinogenes (Bokranz et al. 1983; Macy et al. 1986; Klimmeck et al. 1991) and Sulfurispirillum deleyianum (Schumaher et al. 1992; Eisenmann et al 1995) are also capable of reversed reaction of sulfide oxidation to sulfur, for which polysulfide reductase is held responsible (Krafft et al. 1995), but the oxidation of sulfide was observed both in the presence of nitrate and fumarate as the electron acceptor. This indicates that the conditions whereby sulfur and nitrogen species can be interconverted within the same ecological niche might be common in certain natural habitats as well as in the industrial bioreactors.

Influence of $\mathrm{pH}$ and salts on the growth of strain SR $1^{\mathrm{T}}$ was examined using nitrate as electron acceptor. The results demonstrated that the reactor isolate is a moderate, but obligate haloalkaliphile (Fig. 4). Growth at a salt content between 1.5 and $2.5 \mathrm{M} \mathrm{Na}^{+}$was only possible after gradual adaptation, but not directly using the cells from the low-salt cultures.

Genetic analysis

The $\mathrm{G}+\mathrm{C}$ content in the genomic DNA of strain SR $1^{\mathrm{T}}$ was $44.8 \pm 0.5 \mathrm{~mol} \%\left(T_{\mathrm{m}}\right)$. Phylogenetic analysis based on nearly complete sequence of the $16 \mathrm{~S}$ rRNA gene placed the novel isolate into a deep bacterial lineage with the arsenate- and nitrate-respiring anaerobic bacterium Chrysiogenes arsenatis as the closest described relative (Fig. 5). Low sequence similarity (91\%) indicated that SR $1^{\mathrm{T}}$ represents a new genus within the family Chrysiogenetes. Among the unrecognized members of this group, SR $1^{\mathrm{T}}$ had a much closer relative, strain TE37, which has recently been isolated as an iron reducer from the deep-subsurface alkaline fluids within the Chinese Continental Drilling project (Zhang et al. 2005). Sequence similarity of $98 \%$ indicated relation on the species level (Fig. 5). It seems not a mere coincidence, since the dominant sulfuroxidizing bacterium from the same bioreactor (Thioalkalivibrio $\mathrm{sp}$.) turned out to have a very close relative among one of the clones (CCSD_DF730_B8) identified

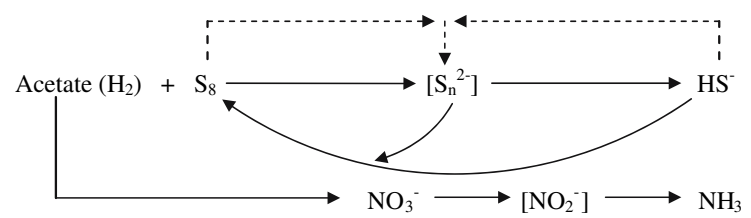

Fig. 3 Scheme of red-ox interaction of sulfur and nitrogen catabolism in SR 1. Dashed lines indicate spontaneous reaction
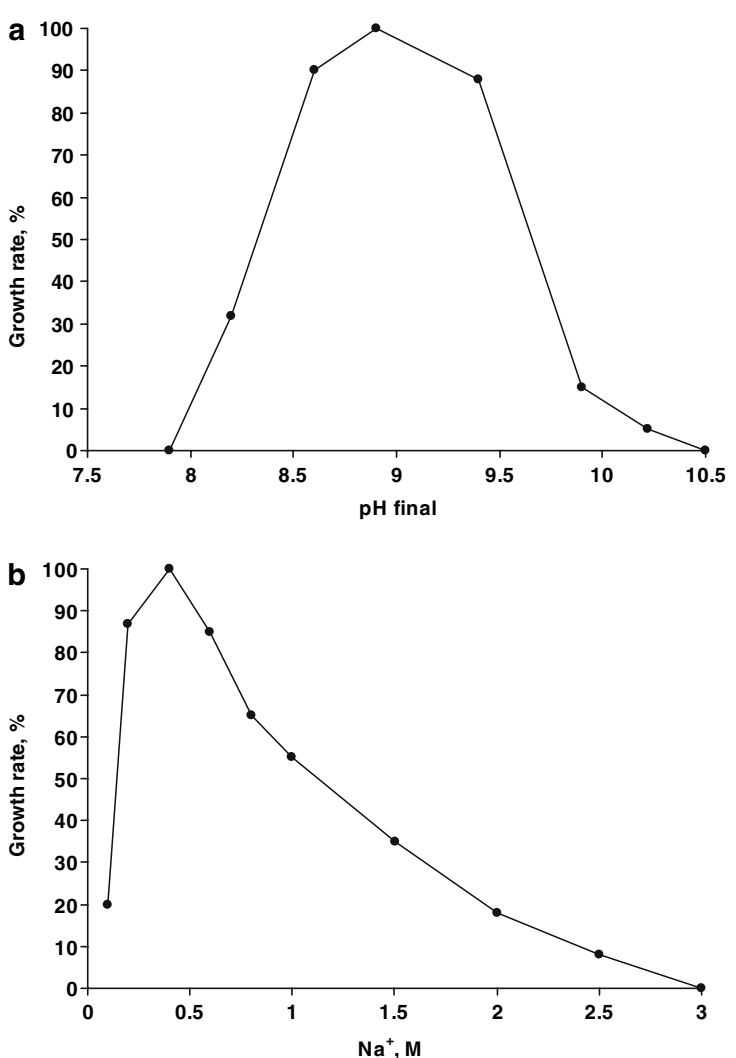

Fig. 4 Influence of $\mathrm{pH}$ at $0.6 \mathrm{M} \mathrm{Na}^{+}$(a) and sodium carbonate/ bicarbonate at $\mathrm{pH} 9(\mathbf{b})$ on anaerobic growth of strain SR 1 with acetate and nitrate

within the Chinese Continental Drilling project (our unpublished results).

\section{Chemotaxonomy}

Examination of the respiratory lipoquinone composition in SR 1 indicated that menaquinones were the sole respiratory lipoquinones present, and were dominated by the MQ-8. The major polar lipids were phospholipids, no evidence being found for glycolipids or amino acid based lipids. The major components were phosphatidylglycerol, and phosphatidylethanolamine, with smaller amounts of an unidentified phopsholipid, diphosphatidylglycerol, together with traces of two additional unidentified phospholipids and an aminophospholipid. The fatty acids were dominated by the 18:1w7c species. Interestingly, SR 1 also contained multiple isomers of unsaturated 16:1 fatty acids (Table 1). In addition a single unidentified derivative of a 3-OH amide-linked fatty acid was detected, which might be an indicative of the presence of a cell wallbound lypopolysaccharide.

Overall, strain SR $1^{\mathrm{T}}$, isolated from sulfide-removing haloalkaline bioreactor, represents a first example of 
Fig. 5 Phylogenetic position of strain SR $1^{\mathrm{T}}$ based on $16 \mathrm{~S}$ rDNA gene sequence analysis. The tree was constructed using maximum likelihood method and filter. The scale bar represents 10 nucleotide changes per 100 nucleotides. The percentage of bootstraps was derived from 1,000 resampling using neighbour joining algorithm, only values greater than 95 are given. The sequence of Thermotoga maritima was used as an outgroup

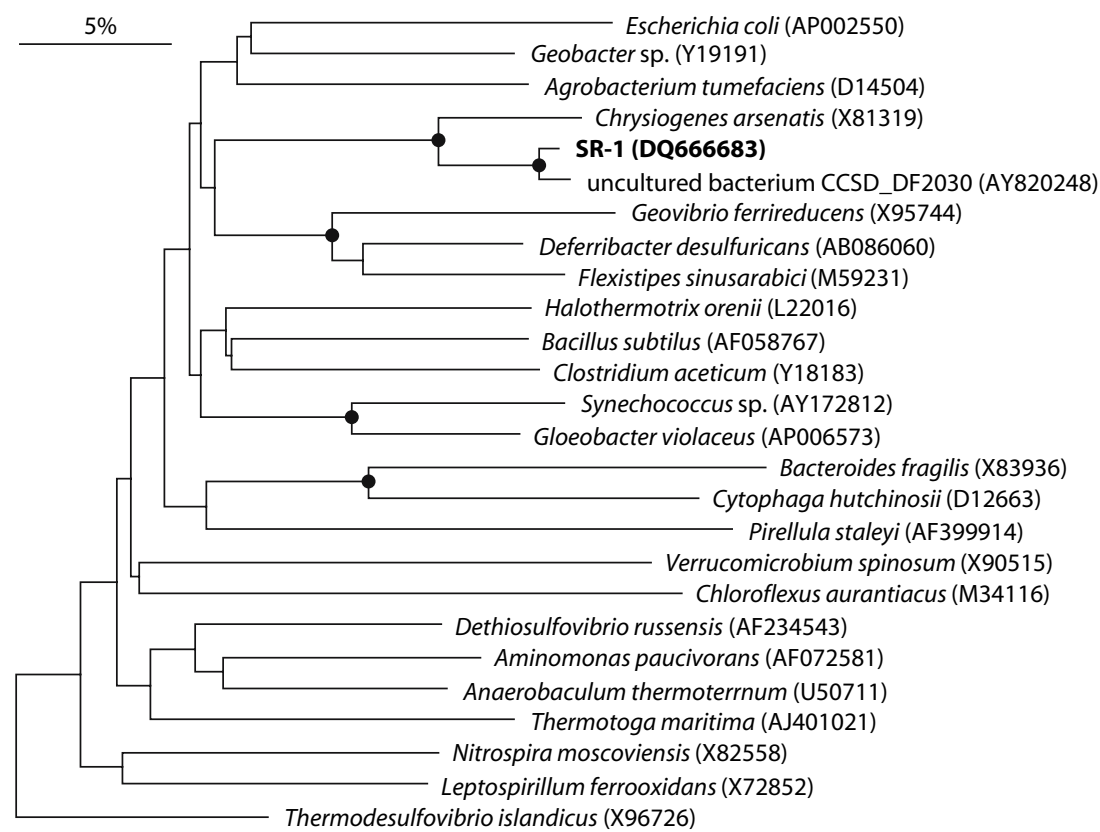

Table 1 Fatty acid composition of polar lipids in SR 1

\footnotetext{
${ }^{a}$ Indicates uncertain identification

b Indicates amide-linked fatty acid
}

\begin{tabular}{|c|c|}
\hline Fatty acid & $\begin{array}{l}\text { Percentage } \\
\text { from total }\end{array}$ \\
\hline $12: 1$ & 3.6 \\
\hline $12: 0$ & 2.3 \\
\hline $3 \mathrm{OH} 12: 1^{\mathrm{a}}$ & 2.3 \\
\hline $3 \mathrm{OH} 14: 1^{\mathrm{a}, \mathrm{b}}$ & 2.3 \\
\hline $16: 1 \mathrm{a}$ & 1.3 \\
\hline $16: 1 w 7 c$ & 5.3 \\
\hline $16: 1 b$ & 3.9 \\
\hline $16: 0$ & 15.3 \\
\hline Cyclo 17:0 & 1.3 \\
\hline $18: 1 \mathrm{w} 7 \mathrm{c}$ & 57 \\
\hline Methyl 18:1 & 2.9 \\
\hline $18: 0$ & 3.7 \\
\hline
\end{tabular}

an obligatory anaerobic sulfur- and dissimilatory nitrate- reducing alkaliphile. Although it shares several key physiological properties with some mesophilic members of the Epsilonproteobacteria, its distant phylogenetic position and haloalkaliphily makes it unique. Therefore, the new isolate is proposed to be assigned into a new genus and species Desulfurispirillum alkaliphilum within the family Chrysiogenetes. The phenotypic comparison of SR $1^{\mathrm{T}}$ with its closest culturable relative and Epsilonproteobacteria with similar metabolism is given in Table 2 .

\section{Description of Desulfurispirillum gen. nov. sp. nov.}

Desulfurispirillum (De.sul.fu.ri.spi.ril' lum. L. pref. de from; L. n. sulfur sulfur; Gr. n. spira spiral; M. L. dim. neut. n. Spirillum a small spiral. M. L. neut. n.
Desulfurispirillum a spirillum that reduces elemental sulfur).

Gram-negative, motile spirillas. Obligately anaerobic with respiratory metabolism. Use elemental sulfur and nitrate as electron acceptors, and short-chain fatty acids and hydrogen as electron donors. Do not grow autotrophically. Alkaliphilic and slightly halophilic. Menaquinones are the dominant respiratory lipoquinones. Phosphatidylglycerol and phosphatidylethanolamine are the dominant polar lipids and belongs to the family Chrysiogenetes. The type species is D. alkaliphilum.

\section{Description of Desulfurispirillum alkaliphilum sp. nov.}

alkaliphilum (al.ka.li.phi'lum M.L. n. alkali soda ash; Gr. adj. phylum loving; M.L. adj. alkaliphilum loving alkaline conditions)

Cells are slender spirals, $0.15-0.20 \times 2-5 \mu \mathrm{m}$, motile by single bipolar flagella, gram-negative and strictly anaerobic with respiratory metabolism. Use elemental sulfur, polysulfide, nitrate and fumarate as electron acceptors. The final products are sulfide and ammonium. Obligatory heterotrophic. Utilizes short-chain fatty acids, such as acetate, lactate, pyruvate, propionate, citrate and fumarate as electron donor, and carbon source; $\mathrm{H}_{2}$ can be used as electron donor. Formate and methanol are not utilized. Can oxidize sulfide/ polysulfide to elemental sulfur intracellularly in the presence of nitrate as electron acceptor. Moderately 
Table 2 Phenotypic comparison of strain SR 1 and related bacteria

\begin{tabular}{|c|c|c|c|c|}
\hline \multirow[t]{2}{*}{ Characteristics } & \multicolumn{2}{|l|}{ Chrysiogenetes } & \multicolumn{2}{|l|}{ Epsylonproteobacteria } \\
\hline & SR 1 & $\begin{array}{l}\text { Chrysiogenes } \\
\text { arsenatis }\end{array}$ & Wolinella succinogenes & Genus Sulfurispirillum \\
\hline Cell morphology & $\begin{array}{l}\text { Spirillum, single polar } \\
\text { flagellum }\end{array}$ & $\begin{array}{l}\text { Vibrio, single polar } \\
\text { flagellum }\end{array}$ & $\begin{array}{l}\text { Spirillum, single polar } \\
\text { flagellum }\end{array}$ & $\begin{array}{l}\text { Spirillum, single polar } \\
\text { flagellum }\end{array}$ \\
\hline Autotrophic growth & - & - & - & + \\
\hline \multicolumn{5}{|l|}{ Electron donors } \\
\hline $\mathrm{H}_{2}$ & + & - & + & + \\
\hline Formate & - & - & + & + \\
\hline $\mathrm{HS}^{-}$ & + & n.d. & + & + \\
\hline $\begin{array}{l}\text { Acetate, fumarate, succinate, } \\
\text { lactate, pyruvate }\end{array}$ & + & + & + & + \\
\hline \multicolumn{5}{|l|}{ Electron acceptors } \\
\hline $\mathrm{O}_{2}$ & - & - & + & + \\
\hline Sulfur (polysulfide) & + & - & + & + \\
\hline Nitrate $\left(>>\mathrm{NO}_{2}^{-}>>\mathrm{NH}_{3}\right)$ & + & + & + & + \\
\hline $\mathrm{N}_{2} \mathrm{O}$ & - & - & + & - \\
\hline Fumarate & + & - & + & + \\
\hline Arsenate & - & + & - & $+/-$ \\
\hline DMSO & - & - & + & $+/-$ \\
\hline Selenate & - & - & - & $+/-$ \\
\hline $\mathrm{Fe}^{3+}$ & - & - & - & $+/-$ \\
\hline $\mathrm{S}_{2} \mathrm{O}_{3}^{2-} / \mathrm{SO}_{3}^{2-}$ & - & - & + & $+/-$ \\
\hline \multicolumn{5}{|l|}{ Oxidation of $\mathrm{HS}^{-}$with } \\
\hline Nitrate & + & n.d. & + & + \\
\hline Fumarate & - & n.d. & + & + \\
\hline $\mathrm{pH}$ range (optimum) & $8.0-10.2(9.0)$ & neutrophilic & neutrophilic & neutrophilic \\
\hline Salt range $\left(\mathrm{M} \mathrm{Na}^{+}\right)$ & $0.1-2.5$ & $\mathrm{Na}$-independent & Na-independent & Up to 0.5 \\
\hline Habitat & Bioreactor & Gold mine & Rumen fluid & Marine sediments \\
\hline
\end{tabular}

n.d. not determined, $=$ present,$+/-$ present in some species, - absent

alkaliphilic with a $\mathrm{pH}$ range for growth between 8.0 and 10.2 and an optimum at pH 9.0 and slightly halophilic with a salt range from 0.1 to $2.5 \mathrm{M} \mathrm{Na}^{+}$(optimum at $0.4 \mathrm{M})$. Mesophilic with a maximum temperature for growth at 45 and an optimum at $35^{\circ} \mathrm{C}$. The main respiratory lipoquinone is MQ- 8 . The predominant fatty acids in the membrane lipids include 12:1, 12:0, 16:1a, 16:1b, 16:1w7c, cyclo 17:0, 18:1w7c, 18:0 and a methyl 18:1. The $\mathrm{G}+\mathrm{C}$ content of the genomic DNA is $44.8 \pm 0.5 \mathrm{~mol} \%\left(T_{\mathrm{m}}\right)$.

The type strain is SR $1^{\mathrm{T}}(=\mathrm{DSM} 18274=\mathrm{UNIQEM}$ U250). Isolated from a full-scale sulfide-removing bioreactor in the Netherlands. The GenBank 16S rDNA gene sequence accession number is DQ666683.

Acknowledgments This work was supported by NWO-RFBR (47.011.2004.010), STW (WBC 5939), Program of the Russian Academy of Sciences "Molecular and Cell Biology" and RFBR (04-04-48647). We are grateful to P. Luimes for providing samples from the Thiopaq bioreactor.

\section{References}

Bokranz M, Katz J, Schröder I, Roberton AM, Kröger A (1983) Energy metabolism and biosynthesis of Vibrio succinogenes growing with nitrate or nitrite as terminal electron acceptor. Arch Microbiol 135:36-41

Buisman CJN (1989) Biotechnological sulfide removal with oxygen. Ph.D. Thesis, Wageningen University, pp 97-107

Buisman C, Geraats P, Ijspeert P, Lettinga G (1990) Optimization of sulphur production in a biotechnological sulphideremoving reactor. Biotechnol Bioeng 35:50-56

Eisenmann E, Beuerle J, Sulger K, Kroneck PMH, Schumacher W (1995) Lithotrophic growth of Sulfurospirillum deleyianum with sulfide as electron donor coupled to respiratory reduction of nitrate to ammonia. Arch Microbiol 164:180-185

Marmur J (1961) A procedure for isolation of DNA from microorganisms. J Mol Biol 3:208-214

Janssen AJH, Meijer S, Bontsema J, Lettinga G (1998) Application of the redox potential for controlling a sulfide oxidizing bioreactor. Biotechnol Bioeng 60:147-155

Janssen AJH, de Keizer A, van Aelst A, Fokkink R, Yangling H, Lettinga G (1996) Surface characteristics and aggregation of microbiologically produced sulphur particles. Colloids surf B Biointerfaces 6:115-129

Jones BE, Grant WD, Duckworth AW, Owenson GG (1998) Microbial diversity of soda lakes. Extremophiles 2:191-200

Klimmek O, Kröger A, Steudel R, Holdt G (1991) Growth of Wolinella succinogenes with polysulphide as terminal acceptor of phosphorylative electron transport. Arch Microbiol 155:187-192

Krafft T, Gross R, Kröger A (1995) The function of Wolinella succinogenes psr genes in electron transport with polysulphide as the terminal electron acceptor. Eur J Biochem 230:601-606 
Labrenz M, Lawson PA, Tindall BJ, Collins MD, Hirsch P (2005) Roseisalinus antarcticus gen. nov., sp. nov., a novel aerobic bacteriochlorophyll $a$-producing alpha-proteobacterium isolated from hypersaline Ekho Lake, Antarctica. Int J Syst Evol Microbiol 55:41-47

Ludwig W Strunk O, Westram R, Richter L, Meier H, Yadhukumar, Buchner A, Lai T, Steppi S, Jobb G, Forster W, Brettske I, Gerber S, Ginhart AW, Gross O, Grumann S, Hermann S, Jost R, Konig A, Liss T, Lussmann R, May M, Nonhoff B, Reichel B, Strehlow R, Stamatakis A, Stuckman N, Vilbig A, Lenke M, Ludwig T, Bode A, Schleifer K-H (2004) ARB: a software environment for sequence data. Nucleic Acids Res 32:1363-1371

Macy JM, Nunan K, Hagen K, Dixon DR, Harbour PJ, Cahill M, Sly LI (1996) Chrysiogenes arsenatis gen. nov., sp. nov., a new arsenate-respiring bacterium isolated from gold mine wastewater. Int J Syst Bacteriol 46:1153-1157

Macy JM, Schröder I, Thauer RK, Kröger A (1986) Growth of Wolinella succinogenes on $\mathrm{H}_{2} \mathrm{~S}$ plus fumarate and on formate plus sulfur as energy sources. Arch Microbiol 144:147-150

Pfennig N, Lippert KD (1966) Über das Vitamin $\mathrm{B}_{12}$-bedürfnis phototropher Schwefel bacterien. Arch Microbiol 55:245-256

Schumacher W, Kroneck PMH, Pfennig N (1992) Comparative systematic study on "Spirillum" 5175, Campylobacter and Wolinella species. Description of "Spirillum" 5175 as Sulfurospirillum deleyianum gen. nov., spec. nov. Arch Microbiol 158:287-293

Simon J (2002) Enzymology and bioenergetics of respiratory nitrite ammonification. FEMS Rev 26:285-309

Sorokin DY, Kuenen JG (2005) Alkaliphilic chemolithotrophs from sodas lakes. FEMS Microbiol Ecol 52:287-295
Sorokin DYu, Kuenen JG, Jetten M (2001) Denitrification at extremely alkaline conditions in obligately autotrophic alkaliphilic sulfur-oxidizing bacterium Thioalkalivibrio denitrificans. Arch Microbiol 175:94-101

Sorokin DY, Tourova TP, Antipov AN, Muyzer G, Kuenen JG (2004) Anaerobic growth of the haloalkaliphilic denitrifying sulphur-oxidising bacterium Thialkalivibrio thiocyanodenitrificans sp. nov. with thiocyanate. Microbiology 150:24352442

Strömpl C, Tindall BJ, Jarvis GN, Lünsdorf N, Moore ERB, Hippe H (1999) A re-evaluation of the taxonomy of the genus Anaerovibrio, with the reclassification of A. glycerini as Anaerosinus glycerini gen. nov., comb. nov., and $A$. burkinabensis as Anaeroarcus burkinabensis gen. nov., comb. nov. Int J Syst Bacteriol 49:1861-1872

Tindall BJ (1990a) Lipid composition of Halobacterium lacusprofundi. FEMS Microbiol Lett 66:199-202

Tindall BJ (1990b A comparative study of the lipid composition of Halobacterium saccharovorum from various sources. Syst Appl Microbiol 13:128-130

Tindall BJ (1996) Respiratory lipoquinones as biomarkers. In: Akkermans A, de Bruijn F, van Elsas D (eds) Molecular microbial ecology manual, Sect 4.1.5, Suppl 1. Kluwer, Dordrecht

Zavarzin GA, Zhilina TN, Kevbrin VV (1999) The alkaliphilic microbial community and its functional diversity. Mikrobiology (Moscow, English Translation) 68:503-521

Zhang G, Dong H, Xu X, Zhao D, Zhang C (2005) Microbial diversity in ultra-high-pressure rocks and fluids from the Chinese Continental Scientific Drilling project in China. Appl Environ Microbiol 71:3213-3227 